\title{
IDENTIFIKASI SAKARIN, SIKLAMAT, DAN NATRIUM BENZOAT SERTA KARAKTERISTIK SUSU KEDELAI YANG DIJUAL DI PASAR TRADISIONAL WILAYAH JIMBARAN, BALI SELAMA PENYIMPANAN
}

\section{IDENTIFICATION OF SACCHARIN, CYCLAMATE, AND SODIUM BENZOATE WITH CHARACTERISTIC OF SOY MILK SOLD IN THE TRADITIONAL MARKET OF JIMBARAN AREA, BALI DURING STORAGE}

\author{
${ }^{1}$ Novelita Olivea Herman, ${ }^{2}$ N. L. Ari Yusasrini*, ${ }^{2}$ I Nengah Kencana Putra \\ ${ }^{1}$ Mahasiswa Program Studi Ilmu dan Teknologi Pangan, Fakultas Teknologi \\ Pertanian, Unud \\ ${ }^{2}$ Dosen Program Studi Ilmu dan Teknologi Pangan, Fakultas Teknologi Pertanian, Unud \\ Kampus Bukit Jimbaran, Badung-Bali
}

\begin{abstract}
This study aims to identify saccharin, cyclamate, and sodium benzoate in soy milk circulating in traditional markets in the Jimbaran region, determine the percentage of soy milk samples in traditional markets in the Jimbaran region that contain saccharin, cyclamate, and sodium benzoate, and determine the characteristic of milk soybeans in the traditional markets of the Jimbaran region, Bali during storage. This study uses a survey method with saturation sampling technique. Saccharin, cyclamate and sodium benzoate were analyzed qualitatively and quantitatively while the characteristic of soy milk were observed included $\mathrm{pH}$, total plate count, and sensory assessment. Saccharin, cyclamate, sodium benzoate, $\mathrm{pH}$, total plate count, and sensory assessment were analyzed using descriptive methods. The results showed that soy milk in traditional markets in the Jimbaran region did not contain saccharin, $80 \%$ used cyclamate, $100 \%$ used sodium benzoate, and characteristics of soy milk in traditional markets in Jimbaran, Bali during 8 hours storage has $\mathrm{pH}$ between 6.8 to 8.34 , as much as $70 \%$ of soy milk has total plate count less than $10^{6} \mathrm{CFU} / \mathrm{ml}$, and it is still well consuming because the color has the like criteria, aroma and flavor has the neutral criteria and very not acidic.
\end{abstract}

Kata kunci: saccharin, cyclamate, sodium benzoate, characteristic soy milk.

\section{PENDAHULUAN}

Susu kedelai adalah produk yang berasal ekstrak biji kacang kedelai dengan air atau larutan tepung kedelai dalam air, dengan atau tanpa penambahan bahan tambahan makanan lain yang diizinkan (SNI 01-3830-1995). Komposisi gizi 100 g susu kedelai diantaranya adalah kalori 41 kkal, protein 3,50 g, lemak 2,50 g, karbohidrat

*Korespondensi penulis : 5,00 g, kalsium 50,00 mg, fosfor 45,00 $\mathrm{g}$, besi $0,70 \mathrm{~g}$, vitamin A $60 \mu \mathrm{g}$, vitamin $\mathrm{B}_{1}$ 0,08 mg, dan vitamin C 2,00 mg (Aman dan Hardjo dalam Budimarwanti, 2018).

Bau dan rasa langu merupakan salah satu masalah dalam pengolahan kedelai. Off flavor dapat dihilangkan dengan cara pemanasan dan penambahan gula sebanyak $5-15 \%$ dari

Email: ariyusasrini@unud.ac.id 
berat susu kedelai (Koswara, 2009). Tidak jarang penggunaan gula alami diganti dengan gula sintetis seperti sakarin dan siklamat untuk menguntungkan produsen.

Kelebihan sakarin menimbulkan dampak bagi tubuh di antaranya adalah migrain dan sakit kepala, kehilangan daya ingat, bingung, insomnia, iritasi, asma, hipertensi, diare, sakit perut, alergi, impotensi dan gangguan seksual, kebotakan, kanker otak dan kandung kemih (Fatimah et al., 2015). Menurut Mudjajanto dalam Nurlailah (2017), penggunaan siklamat diperuntukkan bagi pasien diabetes atau konsumen diet rendah kalori dapat bersifat karsinogenik jika digunakan secara berlebihan dan rutin dalam waktu yang lama. karsinogenik.

Balai Laboratorium Kesehatan Daerah Provinsi Jawa Tengah pernah melaporkan bahwa di Kecamatan Pedurungan, terdapat jajanan yang menggunakan siklamat sebagai pemanis buatan (Sefrina, 2017). Selain itu, dari hasil pengujian sampel BPOM tahun 2011 mencakup wilayah Bandar Lampung, Jakarta, Bandung, Semarang, Yogyakarta, Surabaya, Mataram, dan Makassar menunjukkan bahwa dari 20.511 sampel pangan terdapat sebanyak 416 sampel mengandung siklamat/sakarin yang penggunaannya melebihi batas yang ditentukan
(Mudzkirah, 2016). SNI 01-0222-1995 mempersyaratkan bahwa batas maksimum penggunaan sakarin adalah $300 \mathrm{mg} / \mathrm{kg}$ dan siklamat $3000 \mathrm{mg} / \mathrm{kg}$.

Kendala lain yang dihadapi produsen adalah umur simpan susu kedelai pendek dan cepat rusak jika tidak disimpan di lemari pendingin. Karena memiliki umur simpan yang relatif pendek dan mudah rusak ada kemungkinan produsen yang menggunakan natrium benzoat sebagai bahan pengawet. Ambang batas penggunaan natrium benzoat yang ditetapkan pada SNI 01-0222-1995 adalah sebesar $600 \mathrm{mg} / \mathrm{kg}$. Penggunaan natrium benzoat berlebih dapat menyebabkan kram perut. Dalam pengunaan jangka panjang berpotensi menimbulkan kanker dan merusak system syaraf (Winarno dalam Novian, 2013).

Susu kedelai sudah beredar di berbagai tempat di wilayah Jimbaran seperti di pasar tradisional. Di Kelurahan Jimbaran terdapat 4 pasar yaitu di Jalan Goa Gong, Pasar Desa Jimbaran, Jalan Uluwatu, dan Taman Griya. Penjual susu kedelai di pasar tradisonal wilayah Jimbaran, Bali menyatakan bahwa tidak menggunakan sakarin, siklamat, dan natrium benzoat serta tidak mengetahui susu kedelai dapat bertahan berapa lama di suhu ruang. Susu kedelai yang dijual di pasar 
wilayah Jimbaran belum diketahui secara pasti apakah mengandung sakarin, siklamat, dan natrium benzoat pada susu kedelai. Oleh karena itu, penelitian ini bertujuan untuk mengidentifikasi sakarin, siklamat, dan natrium benzoat pada susu kedelai yang beredar di pasar tradisional wilayah Jimbaran dan mengetahui karakteristik susu kedelai yang dijual di pasar tradisional wilayah Jimbaran, Bali selama penyimpanan. Susu kedelai yang dijual oleh pedagang di pasar wilayah Jimbaran belum diketahui secara pasti apakah mengandung sakarin, siklamat, dan natrium benzoat pada susu kedelai. yang dijual di pasar tradisional wilayah Jimbaran, Bali selama penyimpanan.

\section{METODE PENELITIAN}

\section{Tempat dan waktu}

Penelitian ini dilaksanakan di Laboratorium Biokimia dan Nutrisi Fakultas Teknologi Pertanian, Jalan Raya Kampus Udayana, Bukit Jimbaran, Laboratorium Analisis Pangan, dan Laboratorium Mikrobiologi Pangan Fakultas Teknologi Pertanian, Gedung Agrokompleks Universitas Udayana, Jalan P.B. Sudirman, Denpasar. Pelaksanaan penelitian ini dilakukan pada bulan September hingga November 2019.

\section{Alat dan Bahan}

Alat yang digunakan adalah gelas beaker, erlenmeyer, pipet, pipet volume, bola hisap, waterbath, tabung reaksi, kertas whatmann 42, kertas saring, neraca analitik, vacum rotary evaporator, spektrofotometer uv-vis, labu ukur $100 \mathrm{ml}$, labu ukur $250 \mathrm{ml}$, labu ukur $10 \mathrm{ml}$, corong pisah, desikator, kertas $\mathrm{pH}$, gelas ukur, pipet mikro, batang bengkok, dan petri dish disposable.

Bahan yang digunakan dalam penelitian ini adalah susu kedelai, $\mathrm{HCl}$ $10 \%, \mathrm{HCl} 5 \%, \mathrm{HCl}$ pekat, $\mathrm{H}_{2} \mathrm{SO}_{4}$, resorsinol, aquades, $\mathrm{NaOH} 10 \%, \mathrm{NaOH}$ $1 \mathrm{~N}$, etanol $\mathrm{PA}, \mathrm{NaCl}$ jenuh, dietil eter, $\mathrm{NH}_{3}, \mathrm{FeCl}_{3} 5 \%, \mathrm{BaCl}_{2} 10 \%, \mathrm{NaNO}_{2}$ $10 \%$, natrium benzoat, blanko, PCA, dan $\mathrm{NaCl} 0,85 \%$.

\section{Pelaksanaan Penelitian}

Penelitian ini dilaksanakan dengan pendataan jumlah populasi, pengambilan sampel, melakukan analisis kualitatif terhadap sakarin, siklamat, dan natrium benzoat serta umur simpan. Jika pada sampel teridentifikasi positif pada salah satu parameter atau semuanya, akan dilakukan analisis kuantitatif untuk mengetahui besar kadar tersebut dan disesuaikan dengan SNI NO. 01-02221995. Pelaksanaan penelitian dapat dilihat pada Gambar 1. 


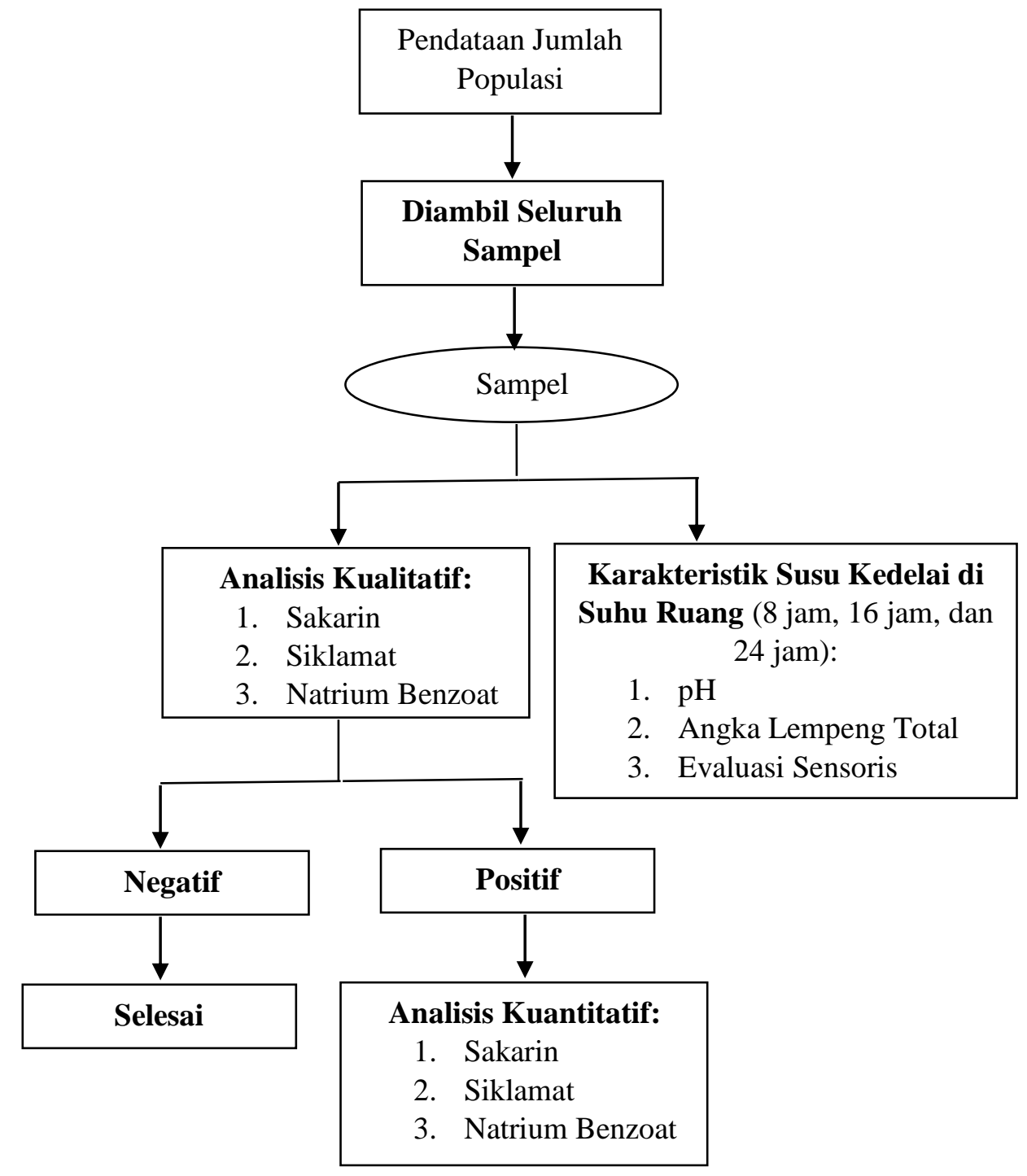

Gambar 1. Pelaksanaan Penelitian

\section{Responden dan Populasi}

Populasi pada penelitian ini adalah 10 sampel susu kedelai di pasar tradisional wilayah Jimbaran. Pengambilan sampel menggunakan metode sampling jenuh sehingga semua populasi dijadikan sampel. Penarikkan sampel menggunakan metode sampling jenuh merupakan teknik penentuan sampel jika semua anggota populasi dijadikan sampel karena kurang dari 30 populasi (Sugiyono, 2010). Selain itu, pengumpulan data dilakukandengan cara wawancara dengan penjual susu kedelai sesuai dengan daftar pertanyaanyang telah dipersiapkan sebelumnya seperti nama, alamat, merk, bahan, umur simpan, proses produksi, dan bahan tambahan pangan.

\section{Analisis Data}

Hasil analisis sakarin, siklamat, natrium benzoat, $\mathrm{pH}$, angka lempeng 
total, dan pengujian sensoris dianalisis menggunakan metode deskriptif. Data penelitian disajikan dalam bentuk tabel.

\section{Variabel yang Diamati}

Analisis kualitatif sakarin dengan metode resorsinol (Karolina et al., 2018), analisis kualitatif siklamat dengan metode pengendapan (SNI 012893-1994), analisis kuantitatif siklamat dengan metode gravimetri (SNI 016684-2002), analisis kualitatif natrium benzoat dengan metode pengendapan (Wardinata et al., 2013), analisis kuantitatif natrium benzoat dengan metode spektrofotometri UV-Vis (Pratiwi 2012), penentuan $\mathrm{pH}$

menurut Soedarmo dalam Astuti (2018), angka Lempeng Total dengan metode total plate count (TPC) (Fardiaz, 1993), dan evaluasi sensoris menurut Susiwi (2009) dilakukan terhadap sampel yang memiliki angka lempeng total sesuai standar BPOM.

\section{HASIL DAN PEMBAHASAN}

Sakarin

Sakarin merupakan pemanis buatan yang terbuat dari garam natrium, natrium sakarin dengan rumus kimia $\mathrm{C}$ ${ }_{7} \mathrm{H}_{5} \mathrm{NO}_{3} \mathrm{~S}$ dari asam sakarin berbentuk bubuk kristal putih, mudah larut air, tidak berbau, dan sangat manis. (Hidayati, 2016). Hasil analisis kualitatif sakarin pada susu kedelai yang dijual di pasar tradisional wilayah Jimbaran dapat dilihat pada Tabel 1.

Tabel 1. Hasil Analisis Kualitatif Sakarin pada Susu Kedelai yang Dijual di Pasar Tradisional Jimbaran

\begin{tabular}{cc}
\hline Sampel & Analisis Kualitatitf \\
\hline $\mathrm{N}_{1}$ & Negatif \\
$\mathrm{N}_{2}$ & Negatif \\
$\mathrm{N}_{3}$ & Negatif \\
$\mathrm{N}_{4}$ & Negatif \\
$\mathrm{N}_{5}$ & Negatif \\
$\mathrm{N}_{6}$ & Negatif \\
$\mathrm{N}_{7}$ & Negatif \\
$\mathrm{N}_{8}$ & Negatif \\
$\mathrm{N}_{9}$ & Negatif \\
$\mathrm{N}_{10}$ & Negatif \\
\hline Persentase & $0 \%$ \\
\hline
\end{tabular}

Dari Tabel 1 diketahui bahwa hasil analisis kualitatif sakarin pada susu kedelai yang dijual di pasar tradisional wilayah Jimbaran adalah negatif. Dapat dikatakan bahwa susu kedelai yang dijual di pasar tradisional wilayah Jimbaran tidak mengandung sakarin.

\section{Siklamat}

Siklamat merupakan pemanis buatan berbentuk kristal putih, tidak berbau, tidak berwarna, mudah larut dalam air, dan kemanisannya kurang lebih 30 kali kemanisan sukrosa. Siklamat dengan nama kimianya natrium sikloheksilsulfamat $\left(\mathrm{C}_{6} \mathrm{H}_{11} \mathrm{NHSO}_{3} \mathrm{Na}\right)$ umumnya dalam bentuk garam kalsium, kalium, dan natrium Siklamat (Munte dalam Rosita, 2014). Hasil analisis kualitatif dan kuantitatif siklamat pada susu kedelai yang dijual di pasar tradisional wilayah Jimbaran dapat dilihat pada Tabel 2 . 
Tabel 2. Hasil Analisis Kualitatif dan Kuantitatif Siklamat pada Susu Kedelai yang Dijual di Pasar Tradisional Wilayah Jimbaran

\begin{tabular}{cccc}
\hline Sampel & Analisi Kualitatif & $\begin{array}{c}\text { Analisis Kuantitatif } \\
(\mathrm{g} / \mathrm{kg})\end{array}$ & $\begin{array}{c}\text { Kesesuaian } \\
\text { dengan SNI 01- } \\
0222-1995(3000 \\
\mathrm{mg} / \mathrm{kg})\end{array}$ \\
\hline $\mathrm{N}_{1}$ & Positif & & Melebihi \\
$\mathrm{N}_{2}$ & Positif & 6,01 & Melebihi \\
$\mathrm{N}_{3}$ & Positif & 7,10 & Melebihi \\
$\mathrm{N}_{4}$ & Negatif & -61 & - \\
$\mathrm{N}_{5}$ & Positif & - & Melebihi \\
$\mathrm{N}_{6}$ & Negatif & - & - \\
$\mathrm{N}_{7}$ & Positif & 18,61 & Melebihi \\
$\mathrm{N}_{8}$ & Positif & 8,74 & Melebihi \\
$\mathrm{N}_{9}$ & Positif & 7,51 & Melebihi \\
$\mathrm{N}_{10}$ & Positif & 11,98 & Melebihi \\
\hline Persentase & & $80 \%$ &
\end{tabular}

Keterangan: $\quad=$ Tidak dilakukan analisis kuantitatif.

Berdasarkan hasil analisis dapat diketahui semua sampel susu kualitatif siklamat pada susu kedelai kedelai yang dijual di pasar tradisonal yang dijual di pasar tradisional wilayah wilayah Jimbaran melebihi batas yang Jimbaran, dari 10 sampel didapati 8 atau disyaratkan. Menurut Mudjajanto dalam $80 \%$ sampel positif mengandung Nurlailah (2017), penggunaan siklamat siklamat dan 2 sampel lainnya tidak mengandung siklamat. Sampel susu kedelai yang positif mengandung siklamat dapat ditemui di keempat pasar tradisional wilayah Jimbaran dengan produsen yang berbeda-beda. Hasil positif ditunjukkan dengan adanya endapan putih kekuningan.

Sampel yang teridentifikasi positif mengandung siklamat kemudian dilanjutkan analisis kuantitatif dengan metode gravimetri untuk menentukan kadar siklamat. Menurut SNI 01-02221995 tentang bahan tambahan pangan, diperuntukkan bagi pasien diabetes atau konsumen diet rendah kalori dapat bersifat karsinogenik jika digunakan secara berlebihan dan rutin dalam waktu yang lama.

\section{Natrium Benzoat}

Benzoat adalah unsur alami yang terdapat pada beberapa tumbuhan dan sering digunakan sebagai anti bakteri atau jamur (Oktoviana, 2012). Hasil analisis kualitatif dan kuantitatif natrium benzoat pada susu kedelai yang dijual di pasar tradisional wilayah Jimbaran dapat dilihat pada Tabel 3. minuman ringan mempunyai ambang batas siklamat sebanyak $3 \mathrm{gr} / \mathrm{kg}$ dihitung sebagai asam siklamat. Dari Tabel 3. 
Tabel 3. Hasil Analisis Kualitatif dan Kuantitatif Natrium Benzoat pada Susu Kedelai yang Dijual di Pasar Tradisional Wilayah Jimbaran

\begin{tabular}{cccc}
\hline Sampel & Analisis Kualitatif & $\begin{array}{c}\text { Analisis Kuantitatif } \\
(\mathrm{mg} / \mathrm{kg})\end{array}$ & $\begin{array}{c}\text { Kesesuaian } \\
\text { dengan SNI 01- } \\
0222-1995(600 \\
\mathrm{mg} / \mathrm{kg})\end{array}$ \\
\hline $\mathrm{N}_{1}$ & Positif & 4.488 & Melebihi \\
$\mathrm{N}_{2}$ & Positif & 6.268 & Melebihi \\
$\mathrm{N}_{3}$ & Positif & 3.067 & Melebihi \\
$\mathrm{N}_{4}$ & Positif & 7.801 & Melebihi \\
$\mathrm{N}_{5}$ & Positif & 3.056 & Melebihi \\
$\mathrm{N}_{6}$ & Positif & 2.692 & Melebihi \\
$\mathrm{N}_{7}$ & Positif & 2.116 & Melebihi \\
$\mathrm{N}_{8}$ & Positif & 8.547 & Melebihi \\
$\mathrm{N}_{9}$ & Positif & 3.688 & Melebihi \\
$\mathrm{N}_{10}$ & Positif & 6.070 & Melebihi \\
\hline Persentase & & $100 \%$ & \\
\hline
\end{tabular}

Dari Tabel 3. menunjukkan bahwa hasil analisis kualitatif natrium benzoat adalah positif pada semua sampel susu kedelai. Hal ini dapat diketahui dengan terjadinya endapan berwarna merah bata atau cokelat kekuningan. Endapan yang terbentuk terjadi setelah direaksikan dengan pereaksi $\mathrm{FeCl}_{3}$ 5\%. Analisis kualitatif dilakukan untuk mengetahui ada tidaknya natrium benzoat pada susu kedelai. Pereaksi yang digunakan adalah $\mathrm{FeCl}_{3}$ yang dapat membentuk endapan berwarna cokelat jika bereaksi dengan benzoat (Wardinata et al., 2013).

Analisis kuantitatif bertujuan untuk mengetahui kadar natrium benzoat pada sampel susu kedelai. Prinsip kerja analisis kuantitatif natrium benzoat ini adalah dengan penambahan $\mathrm{HCl} 1 \mathrm{M}$ dilakukan untuk mempermudah mendapatkan senyawa asam benzoat yang lebih banyak pada sampel melalui proses hidrolisis yang mana natrium pada struktur natrium benzoat terlepas dan berikatan dengan klorida dari penambahan $\mathrm{HCl}$ dengan membentuk garam yang larut dalam air dan hidrogen akan berikatan dengan karboksilat dan benzene membentuk senyawa asam benzoat. Asam benzoat akan terkestraksi dengan penambahan dietil eter. Adapun reaksi yang terbentuk adalah sebagai berikut:

$$
\begin{array}{r}
\mathrm{C}_{2} \mathrm{H}_{5}-\mathrm{CO}_{2} \mathrm{Na}+\mathrm{HCl} \rightarrow \mathrm{C}_{6} \mathrm{H}_{5} \mathrm{COOH}+\mathrm{NaCl} \\
\text { Penggunaan natrium benzoat }
\end{array}
$$
berlebih dapat menyebabkan kram perut. Dalam penggunaan jangka panjang berpotensi menimbulkan kanker dan merusak sistem saraf (Awang dalam Yulinda, 2015). Natrium benzoat adalah bahan pengawet yang merupakan garam dari asam benzoat di mana memiliki 
lemak tidak jenuh ganda yang telah disetujui penggunaannya oleh FDA (Food and Drug Administration) dan banyak digunakan oleh produsen makanan dan minuman.

\section{Karakteristik Susu Kedelai}

Analisis karakteristik susu kedelai yang dijual di pasar Tradisional wilayah Jimbaran, Bali selama penyimpanan meliputi derajat keasaman

(pH). Angka lempeng total (ALT), dan evaluasi sensoris. Susu kedelai yang diambil untuk dijadikan sampel adalah susu kedelai segar dengan rentang waktu 8 jam setelah proses produksi.

\section{Derajat Keasaman (pH)}

Hasil analisis pH susu kedelai yang dijual di pasar tradisional wilayah Jimbaran, Bali dapat dilihat pada Tabel 4.

Tabel 4. pH Susu Kedelai Susu Kedelai yang Dijual di Pasar Tradisional Jimbaran, Bali Selama Penyimpanan

\begin{tabular}{cccc}
\hline \multirow{2}{*}{ Sampel } & \multicolumn{3}{c}{$\mathrm{Ph}$} \\
\cline { 2 - 4 } & 8 jam & 16 jam & 24 jam \\
\hline $\mathrm{N}_{1}$ & 7,16 & 5,94 & 4,97 \\
$\mathrm{~N}_{2}$ & 6,89 & 6,03 & 4,51 \\
$\mathrm{~N}_{3}$ & 6,82 & 5,01 & 4,39 \\
$\mathrm{~N}_{4}$ & 7,02 & 5,90 & 4,78 \\
$\mathrm{~N}_{5}$ & 6,87 & 5,96 & 4,50 \\
$\mathrm{~N}_{6}$ & 6,89 & 6,24 & 5,06 \\
$\mathrm{~N}_{7}$ & 6,80 & 6,22 & 5,10 \\
$\mathrm{~N}_{8}$ & 7,76 & 5,57 & 4,26 \\
$\mathrm{~N}_{9}$ & 8,34 & 4,80 & 4,33 \\
$\mathrm{~N}_{10}$ & 6,80 & 6,11 & 4,30 \\
\hline
\end{tabular}

Menurut SNI 01-3830-1995, pH susu kedelai berkisar antara 6,5 sampai 7,0. Selama 8 jam penyimpanan, terdapat 6 susu kedelai yang memenuhi syarat SNI yaitu susu kedelai yang dijual di pasar Jalan Goa Gong dan Jalan Uluwatu dengan produsen yang sama, sedangkan 4 lainnya tidak memenuhi. Pada penyimpanan 16 jam dan 24 jam, semua sampel susu kedelai memiliki $\mathrm{pH}$ di bawah syarat yang sudah ditentukan dalam SNI. Penurunan $\mathrm{pH}$ terjadi dikarenakan adanya aktivitas mikroorganisme pada sampel seiringnya bertambahnya waktu dengan kondisi penyimpanan pada suhu ruang. Nilai $\mathrm{pH}$ adalah salah satu indikasi ada tidaknya aktivitas mikroba pada bahan pangan. Perubahan $\mathrm{pH}$ yang relatif kecil dapat menyebabkan perubahan kualitas makanan. Mikroba dapat menghidrolisis atau mendegradasi makromolekul penyusun bahan pangan menjadi fraksifraksi yang lebih kecil di antaranya menghasilkan asam yang dapat menurunkan $\mathrm{pH}$ (Fenema dalam Picauly, 2015) sedangkan menurut Achouri (2007), penurunan $\mathrm{pH}$ merupakan indikator keasaman produk 
yang didapat dari hasil interaksi kimia yang terjadi pada susu kedelai seperti lipolisis dan proteolisis.

\section{Angka Lempeng Total}

Angka Lempeng Total adalah seluruh koloni yang tumbuh pada bahan pangan (BPOM, 2003). Berdasarkan Surat Keputusan Dirjen POM Nomor:
03726 B/SK/VII/89 menyatakan bahwa ALT maksimal pada pangan adalah $10^{6}$ CFU/gram. Hasil analisis terhadap angka lempeng total pada susu kedelai yang dijual di pasar tradisional wilayah Jimbaran selama penyimpanan dapat dilihat pada Tabel 5 .

Tabel 5. Angka Lempeng Total Susu Kedelai yang Dijual di Pasar Tradisional Jimbaran Selama Penyimpanan

\begin{tabular}{cccc}
\hline \multirow{2}{*}{ Sampel } & \multicolumn{3}{c}{ Angka Lempeng Total (CFU/ml) } \\
\cline { 2 - 4 } & $8,76 \times 10^{6}$ & $5,83 \times 10^{6}$ & $1,41 \times 10^{8}$ \\
$\mathrm{~N}_{1}$ & $1,35 \times 10^{4}$ & $1,45 \times 10^{7}$ & $7,62 \times 10^{7}$ \\
$\mathrm{~N}_{2}$ & $1,25 \times 10^{6}$ & $4,90 \times 10^{6}$ & $9,20 \times 10^{7}$ \\
$\mathrm{~N}_{3}$ & $3,53 \times 10^{6}$ & $3,88 \times 10^{6}$ & $6,11 \times 10^{7}$ \\
$\mathrm{~N}_{4}$ & $1,13 \times 10^{5}$ & $9,65 \times 10^{6}$ & $4,76 \times 10^{7}$ \\
$\mathrm{~N}_{5}$ & $1,50 \times 10^{5}$ & $4,87 \times 10^{6}$ & $9,61 \times 10^{6}$ \\
$\mathrm{~N}_{6}$ & $1,85 \times 10^{5}$ & $3,43 \times 10^{6}$ & $7,11 \times 10^{6}$ \\
$\mathrm{~N}_{7}$ & $2,40 \times 10^{4}$ & $1,71 \times 10^{7}$ & $4,54 \times 10^{7}$ \\
$\mathrm{~N}_{8}$ & $2,20 \times 10^{5}$ & $6,52 \times 10^{5}$ & $6,74 \times 10^{8}$ \\
$\mathrm{~N}_{9}$ & $2,58 \times 10^{5}$ & $5,76 \times 10^{6}$ & $7,40 \times 10^{7}$ \\
$\mathrm{~N}_{10}$ & & & \\
Persentase angka & & $10 \%$ & $0 \%$ \\
lempeng total & $70 \%$ & &
\end{tabular}

Hasil analisis ALT susu kedelai yang dijual di pasar tradisional wilayah Jimbaran sebanyak $70 \%$ sampel susu kedelai selama waktu penyimpanan 8 jam memiliki ALT di bawah $10^{6}$ $\mathrm{CFU} / \mathrm{ml}$, sebanyak $10 \%$ sampel susu kedelai selama waktu penyimpanan 16 jam memiliki ALT di bawah $10^{6}$ $\mathrm{CFU} / \mathrm{ml}$, dan semua sampel susu kedelai selama waktu penyimpanan 24 jam memiliki ALT di atas $10^{6} \mathrm{CFU} / \mathrm{ml}$ yang sesuai dengan syarat Surat Keputusan Dirjen POM Nomor: 03726 B/SK/VII/89.
Achouri (2007) menuliskan bahwa kualitas mikrobiologi susu kedelai merupakan faktor penting yang mempengaruhi perubahan kimia selama penyimpanan. Hal ini dapat dilihat dari $\mathrm{pH}$ yang semakin turun dikarenakan mikrobiologi yang menghasilkan asam pada susu kedelai juga semakin banyak. Susu kedelai mempunyai umur simpan 8 jam pada suhu ruang dan 4 hari pada suhu rendah (Wulandari, 2012). Cemaran mikroba yang dapat tumbuh pada susu kedelai adalah kapang, yeast, dan bakteri. 


\begin{abstract}
Penambahan natrium benzoat dalam kadar tinggi (Tabel 3) tidak mempengaruhi jumlah dari angka lempeng total yang diperoleh karena angka lempeng total dari susu kedelai yang didapatkan dari penelitian ini yang memiliki angka kurang dari $10^{-6}$ paling banyak terdapat pada penyimpanan selama 8 jam. Natrium benzoat bekerja dengan optimum pada $\mathrm{pH}$ 2,5-4,0 sedangkan susu Kedelai mempunyai $\mathrm{pH}$ 6,5-7,0 sehingga natrium benzoat tidak cocok digunakan sebagai pengawet untuk produk susu kedelai. Pengetahuan produsen mempengaruhi akan pemilihan jenis pengawet yang cocok untuk

produknya. Menurut (Mz, 2016),
\end{abstract}

pengetahuan produsen dipengaruhi dari beberapa faktor seperti jenjang pendidikan, usia produsen, pengalaman menjadi produsen, dan tingkat kesadaran akan bahaya dari bahan pengawet tersebut.

\title{
Evaluasi Sensoris
}

Angka lempeng total dan $\mathrm{pH}$ susu kedelai yang dihasilkan pada penyimpanan 16 jam dan 24 jam tidak memenuhi syarat yang ditentukan oleh BPOM dan SNI sehingga tidak dilakukan evaluasi sensoris karena dapat membahayakan panelis. Evaluasi sensoris warna, aroma, dan rasa dapat dilihat pada Tabel 6 .

Tabel 6. Hasil Sensoris Warna, Aroma, dan Rasa Terhadap Susu Kedelai yang Dijual di Pasar Tradisional Wilayah Jimbaran, Bali Selama Penyimpanan 8 Jam

\begin{tabular}{cccccc}
\hline \multirow{2}{*}{ Sampel } & \multirow{2}{*}{ Warna (Hedonik) } & \multicolumn{2}{c}{ Aroma } & \multicolumn{2}{c}{ Rasa } \\
& & Hedonik & Skoring & Hedonik & Rasa \\
\hline N1 & 3,56 & 3,84 & 1,92 & 3,48 & 2,00 \\
N2 & 4,24 & 3,96 & 1,76 & 3,96 & 1,76 \\
N3 & 4,36 & 4,04 & 1,76 & 4,20 & 1,64 \\
N4 & 3,40 & 3,68 & 2,08 & 3,28 & 2,24 \\
N5 & 4,28 & 4,00 & 1,88 & 3,76 & 1,84 \\
N6 & 4,20 & 4,00 & 1,88 & 4,12 & 1,64 \\
N7 & 4,16 & 3,92 & 1,84 & 4,12 & 1,68 \\
N8 & 3,44 & 3,92 & 1,72 & 2,96 & 2,04 \\
N9 & 4,12 & 3,88 & 1,72 & 3,72 & 2,04 \\
N10 & 4,24 & 4,00 & 1,88 & 3,96 & 1,80 \\
\hline
\end{tabular}

Tabel 6 menunjukkan bahwa warna dari susu kedelai disukai oleh panelis dengan kriteria suka. Susu yang baik berwarna putih kekuningan dan tidak tembus cahaya. Kerusakkan susu ditandai dengan perubahan warna dari warna aslinya (Nababan et al., 2014).
Susu kedelai tidak lagi homogen akibat adanya pemisahan susu kedelai berupa endapan berwarna putih dan cairan berwarna putih sedikit keruh sehingga mempengaruhi warna. Menurut Stanley (2014), urutan dari perubahan warna susu kedelai dari setelah diproduksi 
sampai tidak layak konsumsi adalah berwarna putih krem kemudian warnanya berubah menjadi krem gelap. Perubahan ini mungkin terjadi karena aktivitas mikroba, setelah terjadi perubahan wana akan terjadi perubahan aroma dan terbentuknya whey.

Aroma didefiniskan sebagai sesuatu yang dapat diterima oleh indra pembau (Febriana, 2014). Tabel 6 menunjukkan bahwa aroma dari susu kedelai dinilai netral untuk penilaian kesukaan oleh panelis dan dinilai sangat tidak asam untuk penilaian skoring. Susu kedelai yang dijual di pasar tradisional wilaayah Jimbaran, Bali tidak menggunakan bahan tambahan perisa sehingga mempengaruhi penilaian hedonik susu kedelai karena Wang (2000), menuliskan bahwa dalam penelitiannya tentang karakteristik varian rasa susu kedelai, susu kedelai dengan rasa cokelat mempunyai nilai tertinggi dibandingkan dengan susu kedelai yang tidak ditambahkan perisa.

$$
\text { Rasa merupakan parameter }
$$
penting yang menyebabkan suatu produk diterima oleh konsumen (Febriana, 2014). Tabel 6 menunjukkan bahwa rasa dari susu kedelai dinilai netral untuk penilaian kesukaan oleh panelis dan dinilai sangat tidak asam untuk penilaian skor. Susu kedelai yang dijual di pasar tradisional wilayah Jimbaran pada lama waktu penyimpanan
8 jam masih disukai dan diterima oleh panelis baik hedonik maupun skor karena keamanan secara mikrobiologi masih aman sehingga tidak ada aroma dan rasa asam akibat aktivitas mikroba. Ikya (2013) dalam penelitiannya tentang efek dari suhu pemasakkan terhadap kualitas susu kedelai didapati bahwa dengan memasak susu kedelai di suhu $100^{\circ} \mathrm{C}$ lebih dapat diterima secara sensoris dibandingkan susu kedelai yang dimasak pada suhu $110^{\circ} \mathrm{C}$

\section{KESIMPULAN DAN SARAN}

Adapun kesimpulan dari penelitian ini adalah:

1. Susu kedelai yang dijual di pasar tradisional wilayah Jimbaran tidak menggunakan sakarin sebagai pemanis buatan tetapi, menggunakan siklamat sebagai pemanis buatan dan natrium benzoat sebagai pengawet buatan.

2. Sebanyak $80 \%$ susu kedelai yang dijual di pasar tradisional wilayah Jimbaran menggunakan siklamat yang kadarnya melebihi ketentuan yang ditetapkan dalam SNI 01-02221995 dan 100\% susu kedelai menggunakan natrium benzoat yang kadarnya melebih ketentuan yangn ditetapkan dalam SNI 01-0222-1995. 
3. Karakteristik dari susu kedelai yang dijual di pasar tradisional wilayah Jimbaran bali selama penyimpanan adalah sebanyak 6 susu kedelai mempunyai $\mathrm{pH}$ yang memenuhi syarat SNI 010222-1995 selama penyimpanan 8 jam, angka lempeng total susu kedelai yang masih memenuhi syarat BPOM sebanyak 70 dari susu kedelai yang disimpan selama 8 jam dan $10 \%$ dari susu kedelai yang disimpan selama 16 jam, serta penilaian sensoris dari susu kedelai masih aman pada penyimpanan selama 8 jam..

Adapun saran dari penelitian ini adalah:

1. Susu kedelai yang disimpan pada suhu ruang masih aman dikonsumsi dengan rentang 8 jam dari waktu produksi.

2. Natrium benzoat tidak cocok digunakan sebagai pengawet pada susu kedelai.

3. Sanitasi yang baik selama produksi susu kedelai akan menghasilkan karakteristik susu kedelai yang lebih baik.

\section{DAFTAR PUSTAKA}

Achouri, A., J. I. Boye., Y. Zamani. 2007. Changes in Soymilk Quality as A Function of Compotition and Storage. Journal of Food 30(5).
Astuti, R. T. 2018. Studi Pembuatan Kefir Susu Kedelai (Glycine max). Skripsi S1. Tidak Dipublikasi. Universitas Muhammadiyah Sumatera Utara.

Badan Pengawasan Obat dan Makanan. 2003. Mutu Pangan. Direktorat Surveilan dan Penyuluhan Keamanan Pangan Deputi III. Jakarta

Badan Standar Nasional. 1995. SNI 013830-1995 tentang Susu Kedelai. Jakarta.

Badan Standar Nasional. 1992. SNI 012893-1994 tentang Cara Uji Pemanis Buatan. Jakarta.

Badan Standar Nasional. 2002. SNI 016684-2002 tentang Minuman Energi. Jakarta.

Badan Standar Nasional. 1995. SNI 010222-1995 tentang Bahan Tambahan Pangan. Jakarta.

Budimarwati. 2018. Komposisi dan Nutrisi pada Susu Kedelai. Staff Pengajar Jurusan Kimia Universitas Negeri Yogyakarta.

Fardiaz, D. S. 1993. Analisis Mikrobiologi Pangan. PT. Raja Grafindo. Depok.

Febriana, A., R. A. Dian dan A. Choirul. 2014. Evaluasi Kualitas Gizi, Sifat Fungsional, dan Sifat Sensoris Sala Lauak dengan Variasi Tepung Beras Sebagai Alternatif Makanan Sehat. Jurnal Teknologi Pangan 3(2).

Hidayati, N. 2016. Analisis Kadar Pemanis Buatan pada Es Krim yang Diperdagangkan di Sekitar Sekolah Dasar Kecamatan Dau Kabupaten Malang. Skripsi S1. Tidak Dipublikasi. Fakultas Keguruan dan Ilmu Pendidikan Universitas Muhammadiyah Malang. Malang. 
Ikya, J. K., D. I. Gernah., H. E. Ojobo dan O. K. Oni. 2013. Effect of Cooking Temperature on Some Quality Characteristics of Soy Milk. Journal of Food Science and Technology 5(5):543-546

Karolina, A. L dan K. Rosmiati. 2018. Uji Kadar Sakarin pada Minuman Ringan Bermerek yang Beredar di Kota Pekanbaru. Jurnal Sains dan Teknologi Laboratorium Medik 3(1): 14-17.

Koswara, S. 2009. Teknologi Pengolahan Kedelai (Teori dan Praktek). Ebookpangan.com.

Mudzkirah, I. 2016. Identifikasi Penggunaan Zat Pengawet Boraks dan Formalin pada Makanan Jajanan di Kantin UIN Alauddin Makassar. Skripsi S1. Tidak Dipublikasi. Fakultas Kedokteran dan Ilmu Kesehatan Universitas Islam Negeri Alauddin Makassar.

Mz, T. M., R. A. Basyamfar., R. Moulana. Kajian Penggunaan Boraks dan Formalin pada Produsen Mi Basah di KotaBanda Aceh dan Aceh Besar. Jurnal Ilmiah Pertanian Unsyiah 1(1).

Nababan, L. A., I. K. Suada dan I. B. N. Swacita. 2014. Ketahanan Susu Segar pada Penyimpanan Suhu Ruang Ditinjau dar Uji Tingkat Keasaman, Didih, dan Waktu Reduktase. Indonesia Medicus Veterinus 3(4):274-282.

Novian, A. 2013. Kepatuhan Diet Pasien Hipertensi. Jurnal Kesehatan Masyarakat 9(1).

Novita, S dan R. Adriyani. 2013. Tingkat Pengetahuan dan Sikap Pedagang Jajanan Tentang Pemakaian Natrium Siklamat dan Rhodamin B. Jurnal Promkes, Vol. 1. No. 2. Hal: 192-200.
Nurlailah., A. A. Nurhayati dan N. Oktiyani. 2017. Analisis Kadar Siklamat pada Es Krim di Kota Banjarbaru. Medical Laboratory Technology Journal 3 (1), 77-81.

Oktoviana, Y., S. Aminah dan J. Sakung. 2012. Pengaruh Lama Penyimpanan dan Konsentrasi Natrium Benzoat terhadap Kadar itamin C Cabai Merah (Capsicum аппиит L). Jurnal Akademi Kimia 1(4): 193-199.

Rosita, E. 2014. Analisis Kandungan Siklamat pada Manisan Buah Kedondong Yang di Pasarkan di Sekitar Kota Meulaboh Kabupaten Aceh Barat. Skripsi S1. Tidak Dipublikasi. Universitas Teuku Umar.

Picauly, P., T, Josefina dan M, Mailoa. 2015. Pengaruh Penambahan Air pada Pengolahan Susu Kedelai. Agritekno, Jurnal Teknologi Pertanian 4 (1).

Pratiwi, N. 2012. Analisis Kadar Natrium Benzoat dalam Sirup Markisa dengan Metode Spektrofotometri UV Vis. Skripsi S1. Tidak Dipublikasi. Universitas Islam negeri Alauddin Makassar.

Sefrina, L. R., H. C. Widya dan Z. Intan. 2017. Studi Deskriptif Bahan Tambahan Kimia Berbahaya pada Jajanan Anak Sekolah Dasar di Kecamatan Pedurungan Kota Semarang. Universitas Singaperbangsa Karawang.

Santri., N. Siska dan N. Tadjuddin. 2015. Analisis Mikrobiologi Beberapa Susu Kedelai Tanpa Merek yang Beredar di Kabupaten Maros Sulawesi Selatan. As-Syifaa 7 (02): 10-138.

Suarti, B., Taufik dan S. Agung. 2014. Pengawetan Susu Kedelai dengan 
Penambahan Nipagin Selama Penyimpanan. Agrium 18(3).

Suradi, K. 2012. Pengaruh Lama Penyimpanan pada Suhu Ruang terhadap Perubahan Nilai $\mathrm{pH}$, TVB, dan Total Bakteri Daging Kerbau. Fakultas Peternakan Universitas Padjajaran.

Susiwi, S. 2009. Penilaian Organoleptik. Universitas Pendidikan Indonesia. Jakarta.

Thamrin, Z., S. Saifuddin dan Zakaria. 2014. Analisis Zat Pemanis Buatan (Sakarin dan Siklamat) pada Pangan Jajanan di SD Kompleks Lariangbangi Kota Makassar. Universitas Hassanudin.

Wang, B., X. L, Youling dan W, Changzheng. 2000. Physicochemical and Sensory Characteristics of Flavored Soymilk During Refrigeration Stirage. Deparment of Food \&
Nutritional Science. Tuskegee University.

Wardinata., Minarni. R. Jura dan I. M. Tangkas. 2013. Penetapan Kadar rodhamin B dan Natrium Benzoat pada Saus Tomat yang Beredar di Wilayah Pasar Inpres Kota Palu. Jurnal Akademi Kimia 2 (4): 209214. Yogyakarta.

Yunita, N. L. P dan N.M Utami, D. 2010. Kualitas Mikrobiologi Nasi Jinggo Berdasarkan Angka Lempeng Total, Coliform Total, dan Kandungan Escherichia coli. Jurnal Biologi XIV (1): 15-19

Yulinda. 2015. Analisis Kadar Pengawet Natrium Benzoat pada Saos Tomat di Pasar Sekip Kota Palembang dan Sumbangsinya pada Materi Zat Aditif pada Makanan di Kelas VIII SMP/MTS. Skripsi S1. Tidak Dipulikasi. Fakultas Tarbiyah dan Keguruan Universitas Islam Negeri Raden Fatah. Palembang 